J.Lake Sci.(湖泊科学), 2016, 28(1): 207-216

DOI 10. 18307/2016. 0124

(C) 2016 by Journal of Lake Sciences

\title{
极端干旱事件中洞庭湖水面变化过程及成因”
}

\author{
吉红霞 ${ }^{1,2}$, 吴桂平 ${ }^{1}$, 刘元波 ${ }^{* * *}$ \\ (1: 中国科学院南京地理与湖泊研究所, 中国科学院流域地理学重点实验室, 南京 210008) \\ (2: 中国科学院大学, 北京 100049)
}

\begin{abstract}
摘 要: 干旱是洞庭湖区长期以来面临的严重自然灾害之一, 给周边人们的生产生活造成了极大的影响. 针对 2006 和 2011 年洞庭湖区发生的极端干旱事件, 借助遥感影像大范围、时空连续的优势, 结合湖区水文气象等观测资料, 从时空两 方面阐释了洞庭湖在典型干旱年份水域分布及变化过程,进一步从温度、降水、径流以及蓄水量等方面对比分析不同干 旱事件发生、发展过程的一致性和差异性. 研究结果表明:2006 年干旱大致从 7 月开始,至 12 月结束. 水面淹没范围由湖 心向周边扩展, 到 7 月达到最大值, 8 月提前进人枯水期, 减小范围主要集中在东洞庭湖外围和南洞庭湖的北边. 2006 年 干旱属于由人湖径流减少主导的水文干旱事件;2011 年的干旱则从 4 月开始, 至 11 月结束, 在 9 月以后干旱继续加重. 水 面淹没范围在 6 月急剧增大且一直到 8 月都维持在较高的水平, 涨水期水面由中心向四周淹没,退水期水面变化范围与 涨水期相反.2011 年干旱是由流域降水减少引起的水文和气象干旱事件. 研究结果揭示了洞庭湖区干旱成因的多样性和 复杂性, 对于制定科学合理的干旱灾害防范措施, 减缓区域的生态环境问题等具有一定的指导和借鉴意义.

关键词: 洞庭湖区; 遥感;水面淹没范围;干旱;成因
\end{abstract}

\section{Sharp change of lake levels during the two extreme droughts and its hydroclimatic processes in Lake Dongting, China}

\author{
JI Hongxia ${ }^{1,2}$, WU Guiping ${ }^{1}$ \& LIU Yuanbo ${ }^{1 * *}$ \\ (1: Key Laboratory of Watershed Geographic Sciences, Nanjing Institute of Geography and Limnology, Chinese Academy of \\ Sciences, Nanjing 210008, P.R.China) \\ (2: University of Chinese Academy of Sciences, Beijing 100049, P.R.China)
}

\begin{abstract}
Lake Dongting has been subjected to drought which threatens grain production and people's lives. For investigation of extreme droughts in 2006 and 2011, water surface changes and its tempo-spatial variation characteristics were identified with data of remote sensing images. The similarities and differences for the two drought events were analyzed from respects of changes in temperature, precipitation, runoff and storage capacity, by using the hydrological and meteorological data. The main results are as follows. The first drought lasted from July to December in 2006. The water area expanded from the lake center to all-around low lands. The peaks occurred at July and receded at August in 2006, where the reduced area focused on periphery of east Lake Dongting and north of south Lake Dongting. Drought was mainly caused by discharge reduction in 2006. While in 2011, drought lasted from April to November, and was aggravated in September. The inundated area increased sharply in June and retained a high level until August. During water rose period, water submerges from the center to the surrounding areas, while in water withdrawal period, change direction of water area reverse of water rose period. Drought was caused by combined effects of hydrological and meteorological factors in 2011. The results revealed that there were diversity and complexity of drought causes in Lake Dongting, which can provide useful guidance and advice for making scientific measures to abate drought disaster.
\end{abstract}

Keywords: Lake Dongting area; remote sensing; water surface range; drought; causes

* 国家重点基础研究发展计划“973”项目(2012CB417003) 和中国科学院南京地理与湖泊研究所“一三五” 战略发展 规划项目 (NIGLAS2012135001) 联合资助.2014-10-17 收稿;2015-05-11 收修改稿. 吉红霞 (1989 ), 女, 硕士研 究生;E-mail:jihongxia1026@163.com.

** 通信作者;E-mail:ybliu@ niglas.ac.cn. 
极端天气事件是气候异常变化的集中表现, 具有发生率小、破坏性大、突发性强和难以准确预测等特 点 ${ }^{[1]}$.IPCC 第四次评估报告指出, 随着全球气温的升高, 强降水、高温热浪、干旱等极端天气事件也将不断增 多增强 ${ }^{[2]}$. 作为我国第二大淡水湖泊, 洞庭湖承纳 “湘、资、沅、澧” 四水, 并吞吐长江, 在调节径流、沟通航运、 繁衍水产和改善生态环境等方面发挥着重要作用 ${ }^{[3]}$. 长期以来, 洞庭湖区旱涝灾害发生率较高, 即使是大水 年也会出现干旱, 只是干旱的范围不同、程度不一 ${ }^{[4]}$. 进人 21 世纪后, 干旱灾害不断发生, 成灾年发生率达 $80 \%$ 以上 ${ }^{[5]}$. 频发的旱灾不仅使洞庭湖水位下降、面积缩小, 而且给湿地生态平衡等带来不利影响, 严重危害 人民的生产生活及生态安全, 造成了巨大的社会经济损失, 成为人们关注的焦点 ${ }^{[6-9]}$. 其中最受瞩目的是 2006 年和 2011 年发生的极端干旱事件.2006 年洞庭湖区遭遇了 30 多年来最严重的干旱, 水位骤降, 在夏季 连创历史新低, 湖区受早面积达 $25 \times 10^{4} \mathrm{hm}^{2}$, 居民和牲畜饮水困难 ${ }^{[10]}$, 损失数亿元. 2011 年, 洞庭湖区遭受 50 年一遇的冬、春、夏连旱, 甚至出现了 1980 年以来同期最低水位, 湖区数十万居民饮水困难,农业和渔业 养殖等损失严重,直接经济损失近百亿元 ${ }^{[11-13]}$.

针对近年来洞庭湖区的极端干旱事件, 一些学者认为气温升高、降水偏少且时空分布不均是导致干旱 的主要原因 ${ }^{[14-16]}$; 同时洞庭湖湖泊调蓄能力下降、湖泊面积锐减、上游来水减少以及人类活动的影响等也是 湖区干旱的重要原因 ${ }^{[17]}$. 王文松等 ${ }^{[5]}$ 认为洞庭湖区的干旱灾害是多种因素共同作用的结果,包括全球变暖 导致的湖区降水减少, 泥沙淤积和大规模的围湖造田造成的湖泊面积和容积缩小, 以及社会经济发展伴随 的工业与生活用水量增加等 ${ }^{[5]}$. 这些研究增进了人们对于湖区干旱成因的基本认识. 由于干旱成因的多因素 性及其复杂性, 目前的干旱研究多基于降水或水位数据为主的统计分析阶段,包括基于极值概念识别干旱 事件和归纳历史干旱的发生规律等 ${ }^{[5,16,18-19]}$. 虽然在长期宏观尺度上干旱事件具有明显的统计特征, 但是独 立干旱事件具有明确的物理过程. 对于独立干旱事件的演变过程及成因进行系统的解析, 更有助于把握极端 干旱事件在时间和空间上的变化规律,为湖区抗旱和水资源利用等提供更有针对性的科学依据.

基于此, 本文针对 2006 和 2011 年洞庭湖区发生的极端水文干旱事件, 拟借助遥感影像, 结合湖区水文 气象等观测资料,对比分析这 2 次极端干旱事件的一致性和差异性, 揭示洞庭湖区干旱成因的多样性和复 杂性, 以期对制定科学合理的干旱灾害防范措施、缓解区域的生态环境问题等提供针对性的指导和建议.

\section{1 研究数据资料}

\section{1 遥感数据}

选取 2000-2012 年间的 Terra/MODIS (MODerate-resolution Imaging Spectroradiometer) 数据来实现对洞 庭湖水域面积提取. 数据通过 NASA (美国国家航空航天局) 网站 (http://ladsweb. nascom. nasa. gov/index. $\mathrm{html}$ ) 获取.MODIS 数据集包含多个数据产品, 本研究使用的 MODIS 产品为 $1 \mathrm{~B}$ 级数据 MOD02 和地理定位数 据 MOD03,数据分辨率分别为 $250 \mathrm{~m}$ (近红色波段) 和 $500 \mathrm{~m}$ (绿色波段). 经过篮选得到无云影像 387 景. MOD02 数据已经过仪器标定, 尚未进行大气校正, 需采用 MOD03 数据进行地理定位. 另外, 由于 MODIS 数 据不同波段的空间分辨率不同, 研究中将 $500 \mathrm{~m}$ 空间分辨率的绿色波段全部重采样为 $250 \mathrm{~m}$. 最后将 MODIS 影像进行镶嵌后按湖区边界进行统一裁剪.

\section{2 非遥感数据}

非遥感数据主要包括洞庭湖湖盆数字地形高程 (DEM, Digital Elevation Model) 数据、水文气象数据 (数 据来源为湖南省水文信息网及中国气象科学数据共享服务网 ) 以及野外调查数据.DEM 数据用于与遥感水 面提取结果进行叠置, 以分析洞庭湖水面的空间变化. 根据枯水季节水体在湖区内的分布特征将洞庭湖 DEM 分为 3 个多边形区域, 自西向东分别是西洞庭湖、南洞庭湖和东洞庭湖. 其中东、南洞庭湖的界线为砧 石山一线,南、西洞庭湖的界线为小河咀经赤山岛到南咀一线. 水文数据包括图 1 所示的湘、资、沅、澧“四 水” 4 个水文站 (湘潭、桃江、桃源、石门) 日径流数据 (1987-2011 年)、长江三口松滋口 (新江口、沙道观)、 太平口(弥陀寺) 和藕池口 (康家岗、管家铺) 5 个水文站径流数据以及城陵矶日径流数据( 1987-2011 年). 气象数据则为洞庭流域 23 个国家气象台站 1953-2011 年长时间序列的逐日降水数据, 其分布如图 2 所示. 野外调查资料包括对洞庭湖野外考察样点的水文气象以及景观信息等, 主要为遥感验证提供数据参考. 


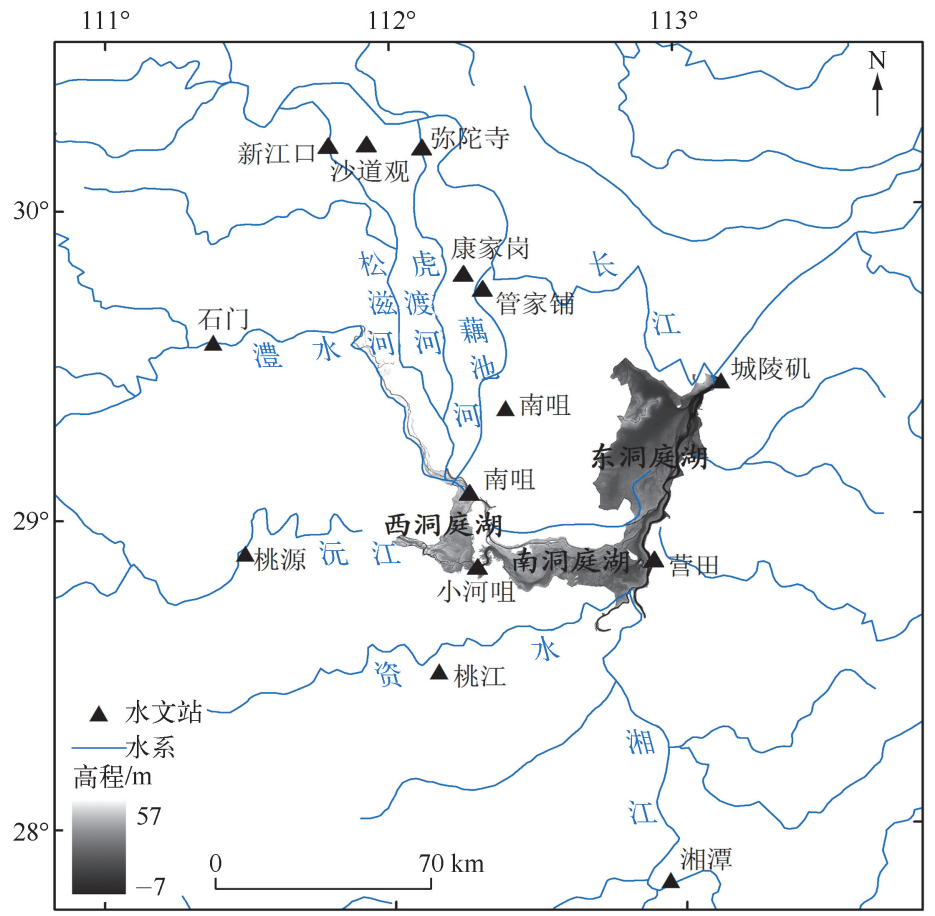

图 1 洞庭湖区水系示意

Fig.1 Location of river system in Lake Dongting area

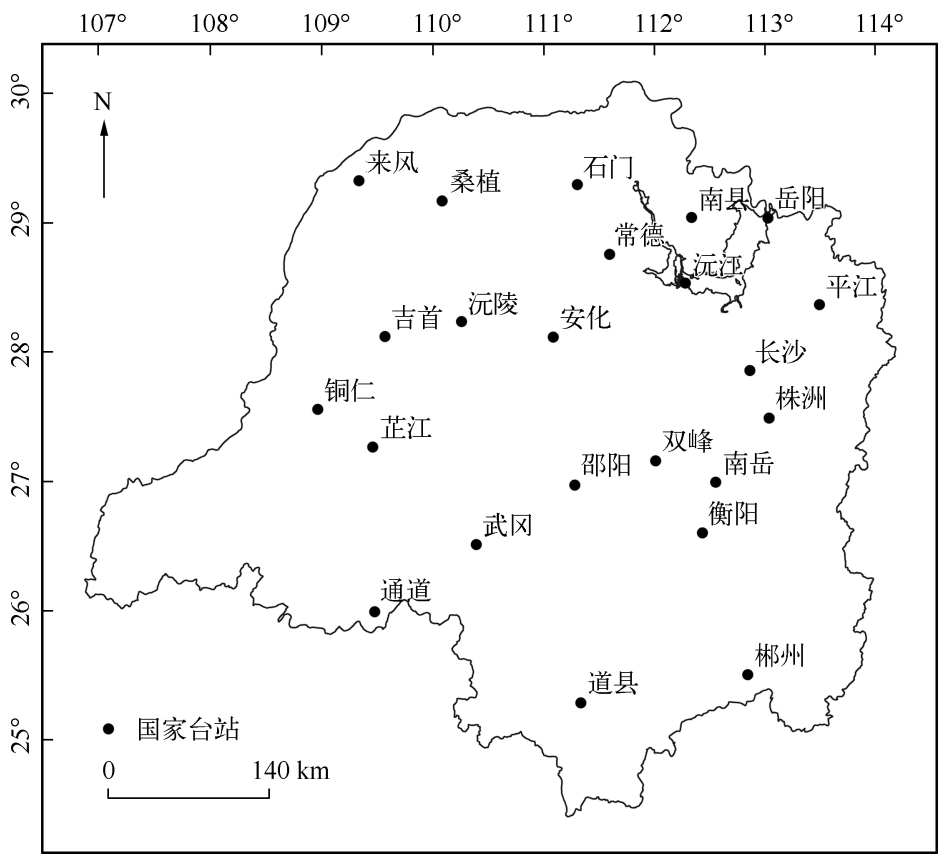

图 2 洞庭湖流域气象台站分布

Fig.2 Distribution of weather stations in Lake Dongting Basin 


\section{2 研究方法}

\section{1 水面淹没范围的提取}

McFeeters ${ }^{[20]}$ 基于绿波段与近红外波段, 提出了归一化水体指数 NDWI( Normal Differential Water Index), 表达式为:

$$
N D W I=\frac{G-N I R}{G+N I R}
$$

式中, $G$ 和 $N I R$ 分别代表绿波段和近红外波段反射率.

研究表明, NDWI 指数可以突出影像中的水体信息, 并能最大程度抑制植被信息 ${ }^{[21]}$, 但阈值的选取具有 很强的主观性. 自组织迭代分类法 (ISODATA, Iterative Self-Organizing Data Analysis Technique Algorithm) 根据 地物光谱特征聚类, 输人参数少, 且受主观因素的影响小. 根据笔者前期研究, 基于 NDWI 的 ISODATA (NDWI-ISODATA) 方法不仅综合了多个波段的水体光谱特征, 同时不需要进行水体阈值的选取, 避免了阈 值选择所带来的主观误差, 更能高精度地提取水面淹没范围 ${ }^{[22]}$. 因而本文采用基于 NDWI 的 ISODATA 分类 法对 MODIS 数据进行洞庭湖水域面积的动态提取.

\section{2 湖区入湖总径流的计算}

洞庭湖区地跨湖南、湖北两省, 湖区江河纵横, 大小湖泊棋布, 入湖水系十分复杂紊乱 ${ }^{[23]}$.虽然可以获得 “三口四水” 的径流资料, 但水文站以下面积仍达 $15200 \mathrm{~km}^{2}$, 径流难以测量. 为估算人湖径流总量, 本文假设 流域和湖区气候条件基本一致,忽略土壤水分变化,可得到以下关系:

$$
\frac{D_{\text {basin }}}{P_{\text {basin }}}=\frac{D_{\text {lake }}}{P_{\text {lake }}}
$$

式中, $D_{\text {basin }}$ 和 $P_{\text {basin }}$ 分别代表洞庭湖流域的径流量和降水量, $D_{\text {lake }}$ 和 $P_{\text {lake }}$ 分别代表湖区的径流量和降水量. 由 此得到湖区径流量为:

$$
D_{\text {lake }}=\frac{D_{\text {basin }}}{P_{\text {basin }}} \cdot P_{\text {lake }}
$$

进而获得人湖径流总量为:

$$
D=D_{\text {lake }}+D_{\text {basin }}
$$

\section{3 结果与分析}

\section{1 干旱的空间变化过程}

2006 年洞庭湖全年水面淹没总体上表现为洪水期 (6-10 月) 汪洋一片, 枯水期 (11 月至次年 5 月) 仅 存几条带状水域的季节性变化特征 (图 3). 其中, 东洞庭湖水面淹没范围最大, 其次为南洞庭湖和西洞庭湖. 从水面淹没范围的逐月空间变化来看, $1-3$ 月水面淹没范围主要集中在洞庭湖 “三口四水” 以及其它河流 人湖的水道和河道中, 这些水域为常年积水区. 4 月份开始, 随着 “四水” 流域进入雨季, 河水上涨, 水面淹没 范围由河道中心向四周不断扩展. 到 7 月份, 洞庭湖 3 个区域几乎全部被水淹没, 水面淹没范围达到最大. 8 月份水面淹没范围迅速减小, 减小范围主要集中在东洞庭湖外围和南洞庭湖的北边. 9 月份后, 随着湖区来 水进一步减少, 水面淹没范围也不断减小, 尤其在东洞庭湖比较明显, 西东洞庭湖水面减小最不显著. 总的来 说, 在洞庭湖涨水阶段, 水面淹没范围扩大的趋势在各个区域表现不同, 东洞庭湖主要表现为由湖心向外逐 渐扩大, 南洞庭湖表现为由北向南延伸, 而西洞庭湖则表现为由目平湖向其西南部逐渐扩大. 退水阶段的水 面范围变化方向与涨水阶段的正好相反. 水面淹没范围的空间变化主要发生在东洞庭湖和南洞庭湖, 西洞庭 湖的变化较小.

2011 年洞庭湖全年水面淹没范围变化趋势与 2006 年大体一致, 但又存在一定的差异 (图 4). 逐月来看 其空间变化, $1-3$ 月水面淹没范围持续较小, 仅在常年积水区的河道和水道中有少量湖水. 4 月开始到 5 月, 


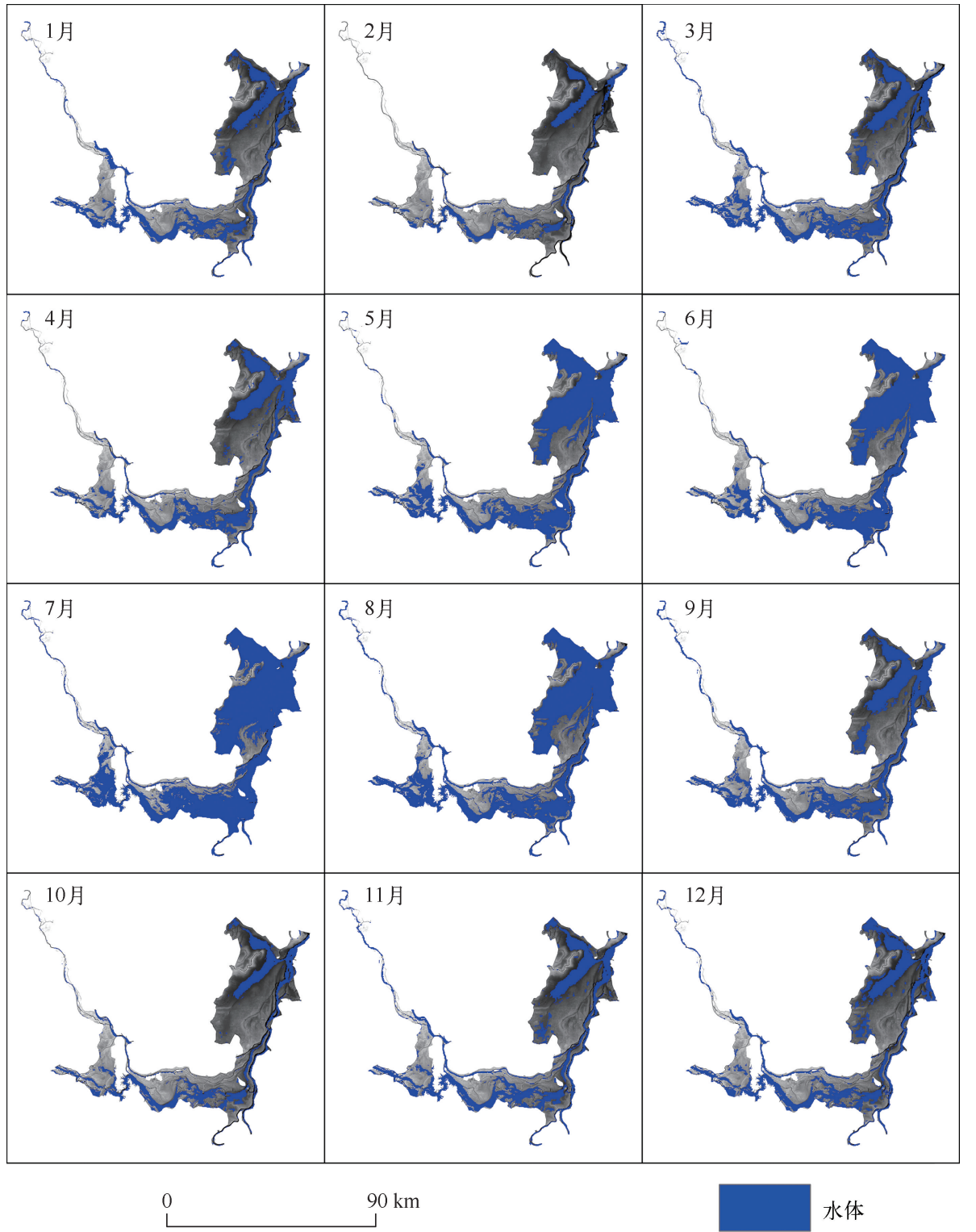

图 32006 年洞庭湖水面淹没范围的空间变化

Fig. 3 Changes of inundated area of Lake Dongting in 2006

随着流域开始进人雨季, 洞庭湖区水面范围并未像往年一样开始向外扩展变大, 主要是由降水偏少造成的.5 月份的水面淹没范围相对 4 月份变化较小. 6 月由于强降雨过程的来临 ${ }^{[24]}$, 水面淹没范围急剧变大, 尤其是 在东洞庭湖和南洞庭湖, 形成了旱涝急转的局面.7 月份水面范围除在东、南洞庭湖继续扩大外, 西、东洞庭 湖水面也开始向外延伸, 到 8 月时整个洞庭湖湖区几乎全部被水淹没, 水面淹没范围达到最大, 这一点与 2006 年的情况有所不同. 9 月份后由于出湖水量大于人湖水量, 水面淹没范围开始向涨水方向相反的方向逐 渐缩小, 直到只剩下常年积水区的水域. 从全年情况来看, 除 $6 、 7$ 和 8 月的淹没范围较大外, 其他月份的水面 淹没范围都比较小,表明 2011 年全年的干旱比较严重.

对比 2006 年和 2011 年干旱事件的空间变化过程发现, 2006 年的水面淹没范围大于 2011 年, 表明 2011 


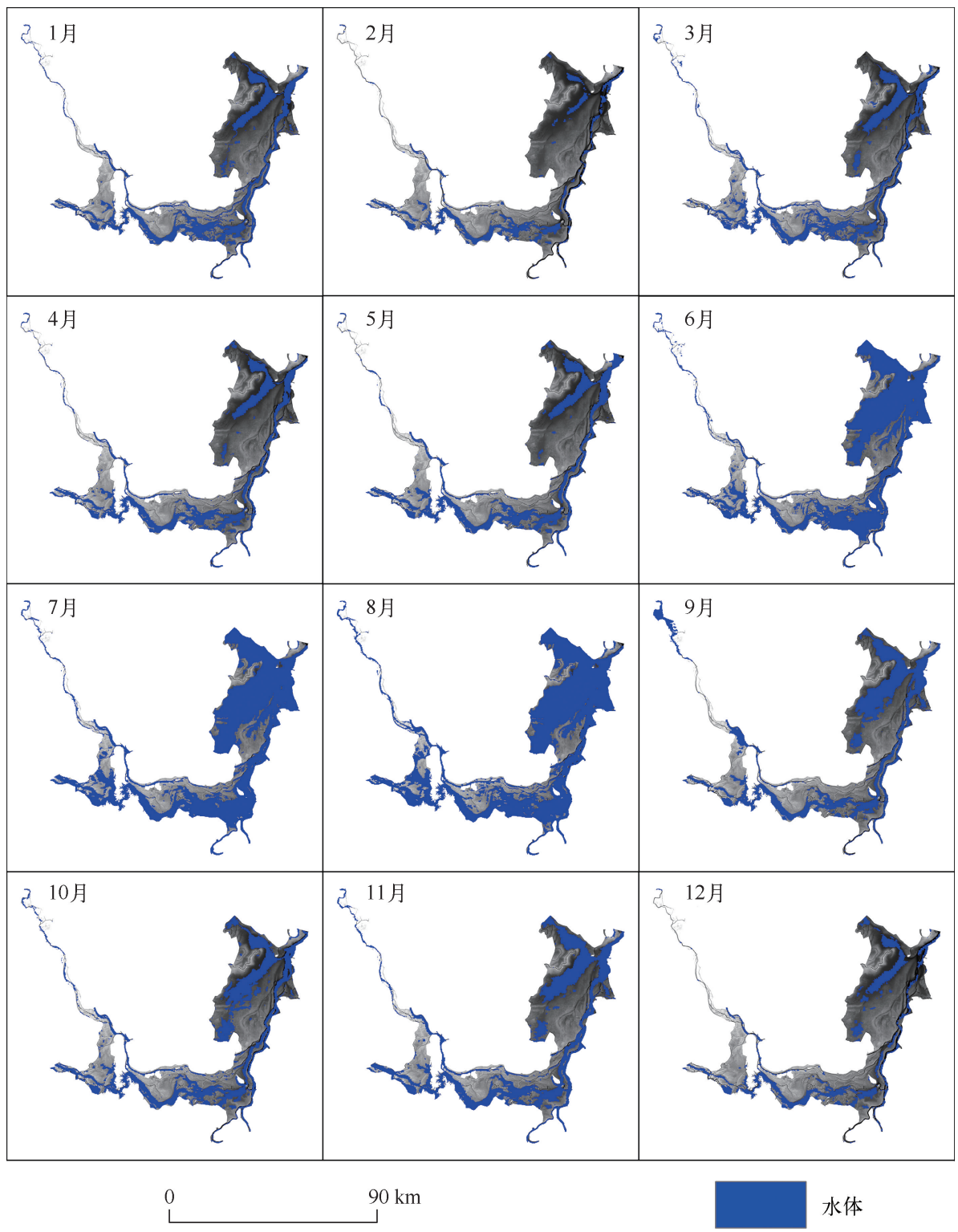

图 42011 年洞庭湖水面淹没范围空间变化

Fig.4 Changes of inundated area of Lake Dongting in 2011

年的干旱更严重一些. 在 1-5 月份,2006 年和 2011 年的水面淹没范围都比较小,集中在东、南、西洞庭湖的 来水河道及水道等常年积水区及其周边,但 2011 年的淹没范围更小. 6 月份时, 2006 年的水面淹没范围继续 维持往年的变化趋势, 但 2011 年由于强降雨的降临使得水面淹没范围迅速向外延伸, 直到 8 月水面淹没范 围一直维持在较高的水平, 而此时 2006 年的水面淹没范围却在 7 月份达到最大后就开始提前进人减小阶 段.从 9 月份开始到 12 月份, 2006 年和 2011 年的水面范围都缩小,但相对 8 月份的水面淹没范围而言, 2011 年 9 月的明显缩小得更快. 因而总的来看,2011 年的干旱程度比 2006 年更严重. 从区域分布来看,2006 年和 2011 年水面淹没范围变化最大的都发生在东洞庭湖, 其次是南洞庭湖, 西洞庭湖的变化最小. 全年在洞庭湖 的水道河道以及主体湖泊均有水面淹没,变化的区域主要在湖区边缘的洲滩地带, 涨水时期与退水时期水 
面淹没范围的变化方向相反.

\section{2 干旱的时间变化过程}

水面面积的大小变化在一定程度上表征了干旱的发生及持续过程. 因此, 本文的干旱时间变化过程主要 基于洞庭湖的水面面积变化特征进行分析. 由洞庭湖水体面积年内逐月变化可知, 2006 年洞庭湖水体面积 变化主要分为两个阶段: 11 月至次年 4 月水体范围较小;5-10 月较大.其中, 2 月份最小, 约为 $329.16 \mathrm{~km}^{2}, 7$ 月份最大, 为 $2048.38 \mathrm{~km}^{2} .2006$ 年洞庭湖水面面积季节变化明显, 除 3 月和 5 月外, 其他各月水面面积均低 于多年平均水平 $(2000-2012$ 年), 且夏、秋季 (6-11 月) 水面面积明显偏小, 水面缩小时间也较为提前, 即 在 8 月湖泊水面便开始急剧变小, 提前进入枯水期. 从各个区域来看, 东洞庭湖的水面面积最大 (143.09 $1082.38 \mathrm{~km}^{2}$ ), 西洞庭湖的水面面积最小 (35.84 253.88 $\left.\mathrm{km}^{2}\right)$, 南洞庭湖的水面面积介于两者之间 ( $150.22 \sim$ $712.13 \mathrm{~km}^{2}$ ). 各个区域的水面面积变化趋势与整个湖体水面面积的变化趋势一致. 总的来看, 东洞庭湖的变 化最大, 西洞庭湖的变化最平缓.

2011 年洞庭湖水面面积变化也可分为与 2006 年相同的两个阶段, 反映出洞庭湖在洪水期东、西、南洞庭 湖连成一片汪洋, 枯水期仅存几条带状水域的季节性变化特征. 全年水面面积 2 月最小, 约为 $379.56 \mathrm{~km}^{2}, 8$ 月 最大, 为 $1681.65 \mathrm{~km}^{2}$. 全年逐月水面面积除 3 月略高外, 其他月份都低于多年平均水平 (2000-2012 年), 尤其 在 4-11 月份比较明显, 表明这一阶段为 2011 年的干旱时期.6-8 月的水面面积相对前期有较大的变化,但未 恢复到正常水平, 因而是干旱缓解阶段, 之后湖区水面面积继续减小, 干旱继续严重化. 各区域的水面面积仍然 是表现为东洞庭湖最大 ( 92.63 951.04 $\left.\mathrm{km}^{2}\right)$, 南洞庭湖次之 (209.19 511.08 $\left.\mathrm{km}^{2}\right)$, 西东洞庭湖最小 ( 77.75 $219.52 \mathrm{~km}^{2}$ ), 变化趋势与湖体整体类似,整个湖区的水面变化在时间和空间上都是一致的 (图 5).

对比 2006 和 2011 年干旱事件的时间变化过程发现,2006 年干旱大约从 7 月开始,到 12 月结束; 2011 年的干旱则从 4 月开始, 11 月结束. 在干旱时期内, 2006 年从 8 月开始水面面积急剧变小, $9-11$ 月的水面面 积与多年平均水平相差较大, 表明这一阶段干旱有所加剧.2011 年的干旱情况相对 2006 年复杂, 从 4 月份开 始进人干旱, 5 月份水面面积与多年平均水平差距拉大, 表明干旱加重, 6-8 月份水面面积在前期基础上急 剧增大, 与多年平均水平差距减小, 说明在这一时期干旱有所缓解, 但并没有达到正常水平, 在接下来的 911 月期间,干旱相对前期又继续加重 (图 5).总的来说,2011 年干旱的持续时间相对 2006 年更长.
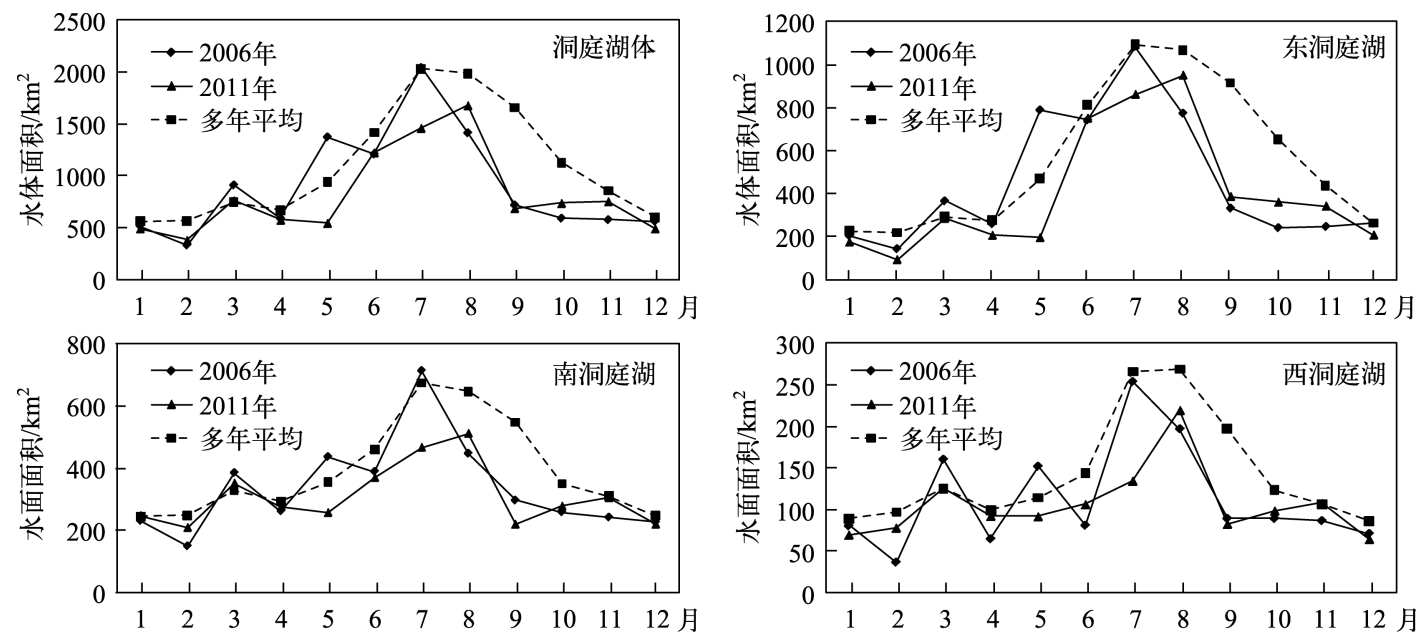

图 52006 、2011 年洞庭湖湖体及东、南、西各区水面面积与多年平均值 (2000-2012 年) 的比较

Fig.5 Water surface area differences in east, south and west Lake Dongting of 2006 and 2011 and multi-year(2000-2012) average

\section{3 干旱事件成因}

2006 年洞庭湖提前进入枯水期,在 7-12 月份出现干旱,原因是多方面的: (1) 从气温来看,2006 年夏 季 6-8 月份,四川、重庆大部分地区持续高温少雨, 先后发生严重干旱 ${ }^{[25]}$, 对长江中下游地区影响严重.洞 


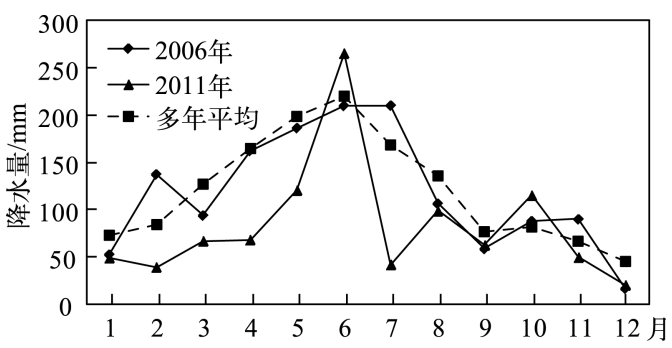

图 62006 、2011 年流域降水量与多年月均降 水量 (1987-2011 年) 的比较

Fig.6 Rainfall differences between 2006,2011 and multi-year( 1987-2011) average

庭湖区在 $35^{\circ} \mathrm{C}$ 以上的高温天气持续时间长, 气温较 多年平均值明显偏高, 高温加剧了水分蒸发和作物 蒸腾, 极大地加重了干旱程度. (2) 从降水量来看, 流域全年总降水量约为 $1408.97 \mathrm{~mm}$, 比多年平均 (1987-2011 年) 降水量偏高 $4.63 \mathrm{~mm}$. 单从全年降 水总量来看, 2006 年降水不属于干旱年份, 但是上 半年和下半年降水特点差异很大.上半年 $1-6$ 月份 除 2 月流域降水量明显偏高多年平均水平 $69.05 \mathrm{~mm}$ 外, 其他月份均低于平均水平.下半年 7-12 月干旱 期降水总量为 $567.42 \mathrm{~mm}$, 比多年平均值略高 $0.99 \%, 7 、 10$ 和 11 月分别偏高 $64.77 、 6.54$ 和 17.46 $\mathrm{mm}, 8 、 9$ 和 12 月的降水量则明显低于多年平均水 平, 分别偏少 $21.16 \% 、 25.97 \%$ 和 62.37\% (图 6), 可 见, 从干旱期的降水总量及逐月降水来看, 除 8、9、12 月降水量偏少明显外, 其他月份的降水量维持在多年 平均水平附近或大于多年平均水平, 从这一方面来看, 流域降水量偏少可能不是 2006 年干旱的主要原因. (3) 从径流来看, 2006 年洞庭湖全年人湖和出湖流量均低于多年平均水平 (图 7a). 水文统计分析得到, $8-$ 11 月,洞庭湖湘、资、沅、澧 “四水” 和松滋、太平、藕池“三口” 分泄人湖的长江人湖水量以及直接人湖的泪罗 江和新墙河等总水量为 $451.44 \times 10^{8} \mathrm{~m}^{3}$, 比历史同期均值 $586.84 \times 10^{8} \mathrm{~m}^{3}$ 偏少 $23.07 \%$. 其中长江“三口” 持续长 时间断流，人湖径流量仅为 $45.50 \times 10^{8} \mathrm{~m}^{3}$, 比多年同期均值偏少 $74.70 \%$. “四水” 人湖水量仅 $297.26 \times 10^{8} \mathrm{~m}^{3}$, 较历年同期偏少 $30.40 \%$. 除湘江略多 1.5 成及资水与历年同期基本持平外,沅水偏少约 6 成, 澧水偏少 9 成. 另外, 城陵矶出湖径流为 $422.61 \times 10^{8} \mathrm{~m}^{3}$, 比历年同期减少约 $52.26 \%$. 湖区出湖总径流减少的比例大于人湖 总径流的比例, 其根本原因在于人湖径流的减少, “三口” 流量创 1980 年以来最低, “四水” 流量则仅次于 1992 年的最低值, 两者共同形成了 2006 年罕见的湖泊秋旱. 这一原因在洞庭湖总入湖径流与出湖径流相减 得到的蓄水量变化 (图 8) 中也可以得到解释.2006 年 7-12 月中,除 7 和 9 月的总人湖径流小于出湖径流, 蓄水量变化为负值, 湖容减小外, $8 、 10 、 11$ 和 12 月的总人湖径流均大于出湖径流, 蓄水量变化为正值, 湖容 增大.这 6 个月的蓄水量变化均大于多年平均蓄水量变化, 而湖泊水面面积相对多年平均却是缩小的, 其根 本原因便在于人湖径流的减少. 另外, 据孙占东等 ${ }^{[26]}$ 的研究显示, 长江上游天然来流量的减少是洞庭湖近年 枯水水情的主因, 三峡蓄水只是起到了加强作用.结合前面对降水的分析可以看出, 2006 年干旱属于“三口 四水”等人湖径流减少主导的水文干旱事件.
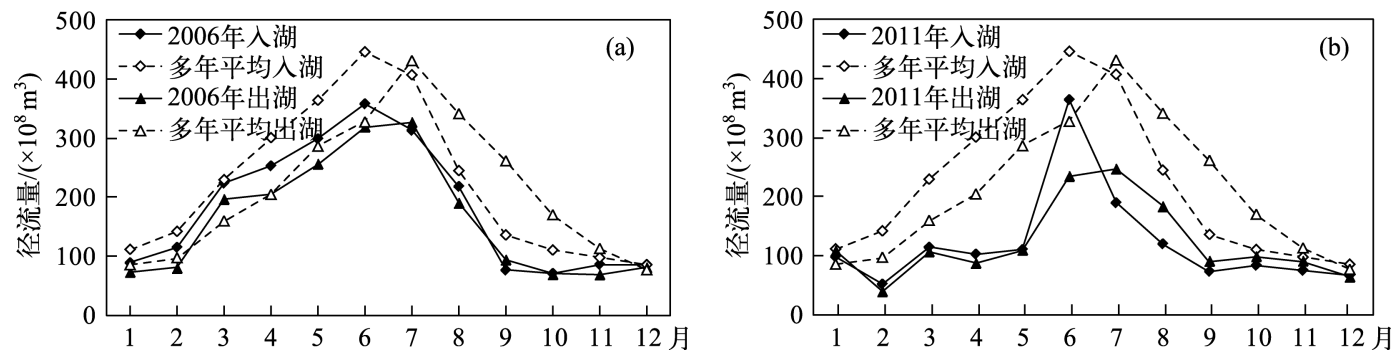

图 72006 、2011 年湖区人出湖径流量与多年平均值( 1953-2011 年) 的比较

Fig.7 Discharge differences between 2006,2011 and multi-year(1953-2011) average

2011 年全年各月的水面面积低于多年平均水平.(1) 从气候的角度来看,影响湖泊面积变化的主要气 候因素是降水,降水亏缺是其他各种干旱的根本原因.流域内的极端降水在一定程度上影响人湖水量, 从而 导致极端水面面积的情况. 2011 年降水量显著减少和雨量在年内分配不均是引起干旱的原因之一.气象资料 显示 (图 6), 2011 年洞庭湖流域全年降水量约为 $993.20 \mathrm{~mm}$, 比多年平均降水偏低约 $29.28 \%$. 在全年 12 个月 
中, 除了 6 和 10 月分别偏多 57.65 和 $25.72 \mathrm{~mm}$ 外, 其余各月降水量持续偏少, 尤其是在干旱期内 $4-5$ 月降 水量总量偏少 $50 \%$ 以上, 7 月的降水量比多年平均偏低最明显,低于多年平均水平 $71.53 \%$,其他月的降水量 低于多年平均水平 $50 \%$ 左右. 可见, 由降水减少所引起的气象干旱对 2011 年洞庭湖干旱产生了较大的影响. (2) 由于降水偏少, 湖区径流量也相应减少, 湖泊蓄水量锐减.上半年至 5 月末, “四水” 主要控制站来水量 $382 \times 10^{8} \mathrm{~m}^{3}$, 较多年同期均值偏少约 50\%, 比历年同期最少年份 (1979 年) 还少 $29 \%$, 为建国以来历年同期最 小值.其中湘、资、沅、澧“四水” 各控制站较历年同期分别偏少 49\%、43\%、50\% 和 $69 \%$ 。“三口” 人湖水量约 $13.70 \times 10^{8} \mathrm{~m}^{3}$, 不及历年同期均值的一半.下半年除 6 月份的人湖径流量较接近多年平均水平外, 其他几个月 的人湖总径流量均与多年平均值相差甚远. 在干旱期 4- 11 月, 总人湖径流量约 $1114.40 \times 10^{8} \mathrm{~m}^{3}$, 比多年平 均水平减少了 $47.01 \%$.相比总人湖径流量, 出湖径 流量减少得更多, 统计结果显示 (图 7b),4-11月 总出湖径流量约为 $1138.86 \times 10^{8} \mathrm{~m}^{3}$, 比多年平均出 湖径流量减少了 $46.69 \%$, 由此将总人湖径流量与 出湖径流量相减得到的蓄水量变化 (图 8) 呈现 46 月为正、7-11 月为负的结果. 在 4-6 月,总人湖 径流量大于总出湖径流量, 蓄水量变化为正, 总的 蓄水量增加,但仍小于多年平均水平; 7-11 月, 总 人湖径流量小于出湖径流量, 蓄水量变化为负, 大 于多年平均水平,但不管哪一阶段, 湖泊水面相对 多年平均值总是缩小的, 其根本原因也是由于人湖 径流量的减少, 从而导致了一系列后续变化, 湖泊 水面呈现出萎缩状态.总的来说, 2011 年干旱属于

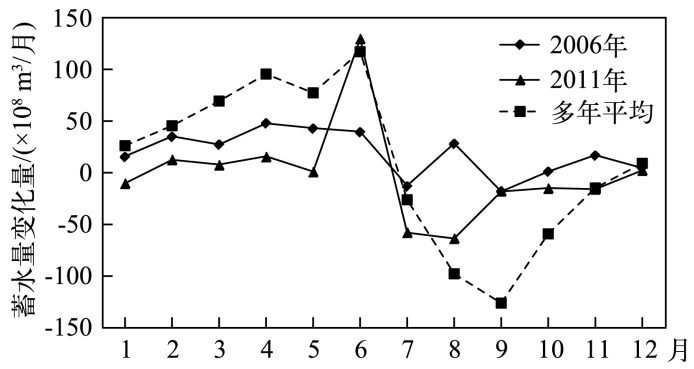

图 $82006 、 2011$ 年蓄水量变化 (总人湖量-总出 湖量) 与多年平均值 (1953-2011 年) 的比较

Fig.8 Storage differences between 2006,2011 and multi-year(1953-2011) average 流域降水减少引起的水文和气象干旱事件.

对比 2006 和 2011 年干旱发生的原因发现,两种干旱事件的主导因素不同.2006 和 2011 年的湖区全年 降水总量均小于多年平均水平, 但从年内逐月降水量来看,在干旱时期内, 2011 年的逐月降水比多年月平均 值偏低得更明显, 说明 2011 年干旱部分是由气象干旱引起的, 而 2006 年逐月降水与多年平均值虽存在差 异,但还不至于引起严重的气象干旱.径流方面来看,2006 和 2011 年的出湖总径流量减少的比例小于人湖 总径流量, 其根本原因都是人湖径流量减少. 人湖径流量减少导致出湖径流量和蓄水量变化的减少.总的来 说,2006 年干旱主要由水文因素引起,2011 年干旱则由水文和气象因素共同引起.

\section{4 结论}

本文基于洞庭湖区水文气象资料以及卫星遥感影像资料, 对 2006 和 2011 年湖区水面进行提取, 针对这 两年发生的极端干旱事件, 阐释洞庭湖的水域分布及变化过程, 对比分析这两个干旱事件发生发展过程的 一致性和差异性,揭示了洞庭湖区干旱成因的多样性和复杂性,得到的主要结论为：

1) 从干旱的空间变化过程来看, 2006 年的水面淹没范围大于 2011 年.2006 年的水面淹没范围在 1-7 月呈增长趋势, 且在 7 月份达到最大, 水面变化方向为由湖心向周边扩散, 8 月以后水面开始急剧缩小, 提前 进人枯水期, 随后水面淹没范围呈减小趋势. 各区域的水面淹没范围变化不同, 东洞庭湖变化最大, 南洞庭湖 次之,西洞庭湖最小. 2011 年的水面淹没范围在 1-5 月份都较小, 6 月份急剧增大且一直到 8 月份都维持在 较高的水平,9月份后水面开始萎缩.各区域的水面淹没范围变化同 2006 年基本类似.

2) 从干旱的时间变化过程来看, 2006 年干旱大约从 7 月开始,到 12 月结束; 2011 年的干旱则从 4 月开 始, 11 月结束.在干旱期内, 2006 和 2011 年的水面面积几乎都低于多年平均水平,但 2011 年的差距更大.干 旱期水面面积的时间变化趋势与空间变化趋势一致.与 2006 年干旱事件不同的是, 2011 年的干旱在 6-8 月 有缓解的过程,但未恢复到正常水平, 因而在 9 月份后干旱继续加重.

3）从干旱事件的原因来看,2006 年干旱属于 “三口四水”等人湖径流减少主导的水文干旱事件,2011 年则是由流域降水减少引起的水文和气象干旱事件. 可见, 洞庭湖区干旱存在着多因素性和复杂性, 为此应 
针对洞庭湖区的具体干旱情况制定科学合理的措施, 加强防旱抗旱工作, 减缓区域生态环境问题.

\section{5 参考文献}

[1] 张万诚, 郑建萌, 任菊章. 云南极端气候干旱的特征分析. 灾害学, 2013, 28(1): 59-64.

[ 2 ] IPCC. Climate change 2007: The physical science basis, summary for policymaker. Geneva; IPCC, 2007.

[3] 窦鸿身, 姜加虎. 洞庭湖. 合肥: 中国科学技术大学出版社, 2000: 3-54.

[ 4 ] 张剑明, 章新平, 黎祖贤等. 近 47 年来洞庭湖区干湿的气候变化. 云南地理环境研究, 2009, 21(5): 56-62.

[ 5 ] 王文松, 冯 畅, 张晓梅等. 洞庭湖区干旱灾害发生的原因分析. 长沙大学学报, 2013, 27(2): 88-90.

[6] 曾庆华, 祝燕德. 中国气象灾害大典・湖南卷. 北京: 气象出版社, 2006: 121-127.

[7] 赵化雄. 洞庭湖区旱涝特征浅析. 灾害学, 2003, 18(1):87-91.

[8] 李景保, 郑云有. 论湖南省水旱灾害的地理规律性. 自然灾害学报, 2000, 9(4): 115-120.

[ 9 ] 袁华斌, 李景保. 湖南省农业干旱灾害特征与洪水资源化. 云南地理环境研究, 2006, 18(5): 14-18.

[10] 李景保, 王克林, 杨 燕等. 洞庭湖区 2000 年一 2007 年农业干旱灾害特点及成因分析. 水资源与水工程学报, $2009, \mathbf{1 9}(6): 1-5$.

[11] http: //news. xinhuanet. com/local/2013-05/11/c_115725074. htm.

[12] 李 成, 李文凯, 彭开先. 干旱对洞庭湖渔业养殖的影响和应对措施. 当代水产, 2011, (7): 48-49.

［13］段海霞，王素萍，冯建英. 2011 年全国干旱状况及其影响与成因. 干旱气象, 2012, 30(1) : 136-147.

[14] 刘兰芳. 干旱灾害对湖南省农业发展的影响及对策. 安徽农业科学, 2007, 35(1): 271-273.

[15] 柳晓甘, 张硕辅. 湖南干旱的成因分析与对策措施. 湖南水利水电, 2000, (3): 46-48.

[16] 陈鲜艳, 周 兵, 钟海玲等. 2011 年长江中下游春旱的气候特征分析. 长江流域资源与环境, 2014, 23(1): 139.

[17] http: //news. sohu. com/20130511/n375548126. shtml.

[18] 李景刚, 李纪人, 黄诗峰等. 基于 TRMM 数据和区域综合 $\mathrm{Z}$ 指数的洞庭湖流域近 10 年旱涝特征分析. 资源科学, 2010, 32(6) : 1103-1110.

[19] 薛联青, 张竞楠, 刘晓群等. 基于改进的综合气象干旱指数的洞庭湖流域干旱时空特征. 河海大学学报: 自然科 学版, 2014, 42(1): 1-6.

[20] McFeeters SK. The use of the Normalized Difference Water Index (NDWI) in the delineation of open water feature. International Journal of Remote Sensing, 1996, 17(7) : 1425-1432.

[21] 严恩萍, 林 辉, 莫登奎. 基于 CIWI 模型的洪湖市水体识别及动态监测. 水生态学杂志, 2011, 32(6) : 14-19.

[22] 吉红霞, 范兴旺, 吴桂平等. 离散型湖泊水体提取方法精度对比分析. 湖泊科学, 2015, 27(2): 327-334. DOI 10. 18307/2015. 0218.

[23] 钟宇平. 荆江四口向洞庭湖分流洪道的演变. 湖南水利, 1988, (增刊) : 35-42.

[24] 杨涵洧. 2011 年夏季中国长江中下游旱涝急转成因分析 [学位论文]. 兰州: 兰州大学, 2013.

[25］周亮广, 王 岽, 戴仕宝等. 长江 2006 年汛期特枯径流分析. 自然资源学报, 2009, 24(3)：448-456.

[26] 孙占东, 黄 群, 姜加虎等. 洞庭湖近年干旱与三峡蓄水影响分析. 长江流域资源与环境, 2015, 24(2): 251. 